\title{
APIE 1920 M. [VYKIUS LIETUVOS KARIUOMENĖJE IR ATSIMINIMŲ AUTORIŲ MATĄ KLIKNĄ
}

\author{
Dr. Aušra Jurevičiūtè \\ Vytauto Didžiojo karo muziejus
}

DOI: https://doi.org/10.47459/ka.2021.36.7

1920 m. vasario 22-24 d. ${ }^{1}$ vykusio Kauno igulos kareiviu sukilimo, dar vadinamo Panemunès sukilimu, priežasčiu buvo keletas. Plk. Jonas Petruitis to meto kariuomenès būkle apibūdino taip: „Kariuomene po ištisu metu kautyniu labai pavargusi, algos keli mènesiai jau negaunamos, maistas labai blogas, be jokios pakaitos. "2 Lietuva rengèsi Steigiamojo Seimo rinkimams, bet Rinkimu istatyme nebuvo numatyta suteikti rinkimu teises kariams. Jame buvo rašoma: „Karininkai, mobilizuotieji karo valdininkai ir kareiviai atstovu nerenka, bet patys atstovais renkami gali büti. "3 Lietuvos priešams, kuriais to meto karinès spaudoje buvo vadinami bolševikai, lenkai ir vokiečiai ${ }^{4}$, tai buvo puiki proga destabilizuoti padèti šalyje. Neramumai prasidejo $1920 \mathrm{~m}$. vasario 20 d. jvairiuose daliniuose, kai agitatoriai sukurste kareivius sukilti ir kelti ịvairius reikalavimus.

Vasario $21 d$. Šančiuose jvyko kareiviu susirinkimas. Jame dalyvavo 200 atstovu. Susirinkimui vadovavo komunistas psk. Petras Mickeliūnas. Buvo surašyti reikalavimai ir vasario $22 \mathrm{~d}$. prie Igulos bažnyčios vykusia-

1 Sukilimo datos įvairiuose šaltiniuose skiriasi: vasario 20-23 d., 21-23 d., 22-23 d. Straipsnyje ịvardyta sukilimo data - vasario 22-24 d., vasario 22 d. - oficiali jo pradžia, mitingas prie Igulos bažnyčios, 24 d.- sukilimo atgarsių kitose igulose, Šiaulių daliniuose ir kt. numalšinimas.

2 Novaitis, A. 1920 metų kareivių sukilimas. Karys, 1961, Nr. 4, p. 103.

3 Valstybès tarybos rinkimų įstatymas, $1919 \mathrm{~m}$. spalio 30 d., str. 2 pastaba, http:// www.xn--altiniai-4wb.info/files/istorija/IH00/1919_Rinkim\%C5\%B3_\%C4\%AF_ Steigiam\%C4\%85ji\%C4\%AF_Seim\%C4\%85_\%C4\%AFstatymas.IH1201.pdf [žr. 2021-03-21] 4 Bandymas sukilti Kauno iguloj. Kariškių žodis, 1920, Nr. 9, p. 66. 
Lietuvos

kariuomenès

kūrèjai

savanoriai prie

savo vèliavos

JAV. Iš kairès:

stovi Matas

Klikna (pirmas),

Petras Bobelis,

Konstantinas

Petrauskas,

Jurgis

Dragūnevičius.

(Lietuvių dienos,

$1956 \mathrm{~m}$.

lapkričio mèn.,

Nr. 9)

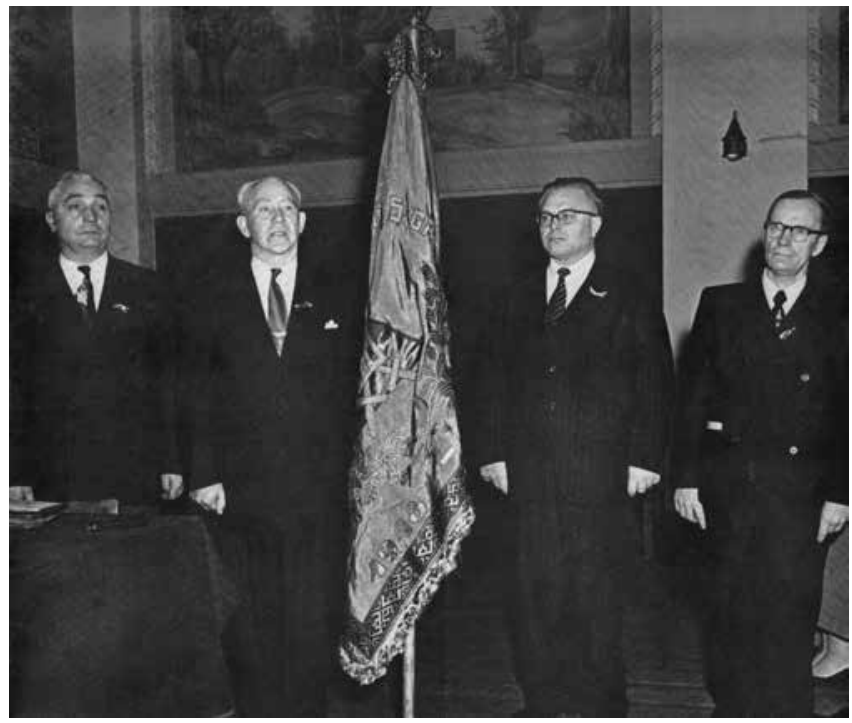

me mitinge perduoti kariuomenès vadovybei - gen. Pranui Liatukui. Jame dalyvave kariai, iteikus reikalavimus, ramiai grižo i kareivines ir jokiu riaušiu nesukèlè. Tačiau sukilo A. Panemunejje dislokuotas artilerijos pulkas ir 2-asis atsargos batalionas - sukilèiai pradejo suiminèti karininkus. Jie suèmè ir ten atvykusi kariuomenès vadą gen. P. Liatuką. Malšinti sukilèliu buvo pasitelkti Šeštojo ir Aštuntojo péstininkų pulkų kareiviai. Tarp sukilèliu ir kariuomenès vyko susišaudymai.

Vasario 23 d. sukilo ir Karo aviacijos specialistu kuopa. Kovoje su sukilèliais, lipdamas i kalna, žuvo JAV kariuomenès vyr. ltn. Samulis Haris (1896-12-24-1920-02-24). Jis tuo metu buvo Lietuvoje su JAV karine misija. S. Haris buvo išvežtas ị JAV ir palaidotas Arlingtono kapinèse. $1920 \mathrm{~m}$. liepos 20 d. JAV lietuviai jam pastate balto marmuro paminkla su Vyčiu, o Lietuvoje 1927 m. - atminimo paminkla Aleksote.

Vasario $24 \mathrm{~d}$. sukilimas numalšintas visose igulose, kuriose buvo prasidejjęs. Maištininkai buvo suimti ir nuteisti: 4 - sušaudyti, 183 - patraukti teisminèn atsakomybèn ${ }^{5}$. Kauno igulos kareiviu sukilimas buvo svarbus to meto ivykis, privertęs kariuomenès vadovybe ir Lietuvos valdžia pakeisti Rinkimu istatyma ir suteikti balsavimo teise kariams.

5 B. P-as. Paminejo nepavykusị sukilimą. Karys, 1955, Nr. 5, p. 156. 


\section{APIE ATSIMINIMŲ AUTORIŲ}

Matas Klikna Martyno gimè 1901-02-10 Sotkalnių kaime, Kražių valsčiuje, Raseinių apskrityje. Tarnavo savanoriu 1919-08-01, pašauktas 1919-10-01-1920-08-18. Dalyvavo kovose su lenkais. 1923 m. baigè Kelių ir tiltų statybos kursus, 1928 m. gyveno Tauragèje, iki 1944 m. tarnavo Plentų ir vandens kelių valdyboje Šiaulių rajone ${ }^{6} .1944$ m. pasitraukè i Vokietiją. 1949 m. atvyko ì JAV. Gyveno Čikagoje, Ilinojaus valstijoje. Buvo vienas Lietuvos kariuomenès kūrèjų savanorių sąjungos steigèjų JAV, Čikagoje, 1949 m. išrinktas ị pirmąją atkurtos organizacijos valdybą ir nuo $1949 \mathrm{~m}$. Sąjungos valdybos sekretorius. Tuo pat metu buvo ịkurtas ir Čikagos skyrius, kurio valdyboje 1953 m. ir 1956 m. dirbo kūrèjai savanoriai plk. ltn. Jonas Švedas, kpt. Povilas Dirkis ir k. v. Matas Klikna7.

M. Klikna buvo apdovanotas Kūrèjo savanorio medaliu (apdovanojimo liudijimas Nr. 2774, išduotas 1929-05-31). Mirè 1984 m. rugpjūčio 14 d. Čikagoje, JAV, palaidotas Šv. Kazimiero lietuvių kapinėse ${ }^{8}$.

6 Lietuvių enciklopedija. Bostonas, t. 12, p. 117.

7 Savanoriai kūrèjai Čikagoje. Karys, 1954, Nr. 5, p. 132.

8 Padèka. Dirva, 1984, Nr. 172, p. 5. 